\title{
SEASONAL AND SPATIAL VARIATION OF PM10 IN AN URBAN AREA FROM ROMANIA
}

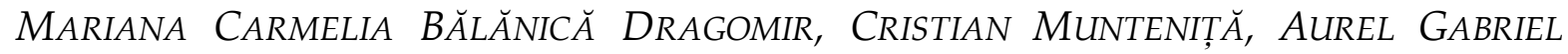 \\ SIMIONESCU, DANIELA ECATERINA ZECA, IRYNA KRAMAR, NATALIIA MARYNENKO
}

\begin{abstract}
The cyclic variance of PM10 mass concentration in the urban area in the South-East of Romania has been analysed in the article. SE of Romania is considered to be a territory which has medium level of pollution for a period of last ten years, from 2009 to 2018. The spatial dispersion of PM10 concentration was obtained using the METI-LIS soft wear for each season. The objective of dispersion models is to evaluate how pollutant concentration is spread out taking in to account the diffusion. The average measurements of PM10 and meteorological parameters as inputs has been used. An evident seasonal change of PM10 concentrations is observed in the article. In order to establish national measures (including economic ones) for the improvement of the atmospheric pollution control it was analysed the mechanism of atmospheric pollution. It was observed that the air quality was overall better in spring and in summer in comparison to the other two periods. With regard to the seasonal variation characteristics of PM10 significant differences for the air quality registered in different months in the researched region were observed. The impact of air temperature on atmospheric pollution was insignificant in spring and autumn; moreover, precipitation was defined as an important influence factor upon the atmospheric pollution. The impact of precipitation on the possibility of atmospheric pollution was obviously different in the four seasons. The research results indicate the meteorological parameters that influence the air pollution become active during the cold seasonal days. It was shown that relative humidity and wind speed are the meteorological parameters that impact the PM10. It was found out that the probability of atmospheric pollution decreased with the increase of air temperature in summer. The research results also testify that the air pollution mapping could be enhanced using atmospheric dispersion models and in-situ measurements.
\end{abstract}

Keywords: PM10, air pollution, meteorological parameters, seasonal variation, dispersion model.

\section{INTRODUCTION}

The paper focuses on the following aspects: (1) characterizing the temporal variations of PM10 in Brăila, Romania during the interval 2009-2018 and (2) analysing the effect of meteorological parameters on the dispersion of PM10. In this paper our intention is paid to the analysis of temporal and spatial dispersion of particulate matter (PM10) and its variation depending on meteorological parameters for the period of 2009-2018. The detailed analysis of meteorological factors' influence on the atmospheric pollution describe exactly the pollutants formation mechanism as well as the dispersion of the 
pollutants under different meteorological conditions and ensure the forecasting of the atmospheric pollution based on meteorological conditions with the aim of decreasing the atmospheric pollution.

The most important atm ospheric pollutants include nitrogen dioxide (NO2), Sulphur dioxide (SO2), particulate matter (PM) and ozone (O3). For several years particulate matter has become one of the major components of atmospheric pollutants due to its effect on public health, namely due to the increase of cardiopulmonary morbidity and mortality $[1 ; 2 ; 3]$.

PM10 consists of inhalable particles with an aerodynamic diameter less than $10 \mu \mathrm{m}$. PM10 originates in several sources including industrial emissions, traffic gases and natural dust [4]. Many studies had shown that PM10 was frequently observed as the most wide-spread atmospheric pollutant in an urban area. Air quality has acquired an increasingly greater importance in recent years with respect to the investigation of the formation mechanism of pollutants and their dispersion depending on certain parameters.

Various studies using air pollutants concentration and meteorological data have concluded that meteorological conditions have direct effects on the dispersion of atmospheric pollution $[5 ; 6 ; 7 ; 8 ; 9]$. Statistical studies have confirmed that there are seasonal and diurnal variations of the atmospheric pollutants depending on meteorological conditions [10].

The atmospheric pollution may be influenced by meteorological conditions directly (atmospheric cycle) or indirectly (traffic during working days, increase in energy consumption for heating in cold seasons) [11; 12; 13].

Meteorological factors have a major importance through the effect of dispersion, transformation and removal of air pollutants from the atmosphere depending on a series of spatial and temporal characteristics.

Seasonal and monthly variability of atmospheric pollution has led to the conclusion that the air quality was the most polluted in spring whereas becoming better in summer with a tendency to increase in autumn and winter. On the whole, atmospheric temperature was the most important meteorological parameter influencing PM10, followed by wind speed, relative humidity, atmospheric pressure and wind direction. Nevertheless, the prevailing meteorological factors that influenced the atmospheric pollution had a different significance throughout the four seasons [14; 15].

The Directive 2008/50/EC was adopted on 1 January 2008 and according to its stipulations the maximum accepted values for PM10 in the European Union are $40 \mu \mathrm{g} / \mathrm{m} 3$ while the short-term maximum value refers to the fact that the 24-hour average of $50 \mu \mathrm{g} / \mathrm{m} 3$ is not to be exceeded more than 35 times a year. EU had assumed many directives and strategies in order to reduce the atmospheric pollution and to im prove air quality [16;17]. Air pollution is a frequent phenomenon in the developing countries.

The permanent monitoring of air pollutants concentration as well as the analysis based on the dependence between meteorological parameters and PM10 would have significant results in reducing atmospheric pollution.

\section{RESUlts}

In order to establish national measures for the improvement of the atmospheric pollution control it is very important to analyse the mechanism of atmospheric pollution.

Hourly PM10 concentration data were collected over a 10 years period from 2009 to 2018 by the Local Environmental Protection Agency observation stations, which are distributed crosswise the city. In our study, we analyse the relationships between PM10 and six meteorological parameters: relative humidity, atmospheric pressure, air temperature, relative humidity, wind speed, wind direction and precipitation.

The METI-LIS, model ver. 2.03 is a Gaussian dispersion model and calculates, in steps of one hour, the pollution dispersion in lower atmosphere using the pollutant concentrations and meteorological data. Wind direction, wind speed and atmospheric stability have a major contribution to dispersion. 
The METI-LIS model includes the downdraft effect, which often influences the atmospheric dispersion from lower emission sources and gives solutions of simple Gaussian plume and puff formula [18] for elevated sources [19].

The parameters in the dispersion widths describing the downwash effect are based on that of the US Environmental Protection Agency's (EPA) Industrial Source Complex (ISC) model. Sources with line-shaped characteristics are calculated in the model by numerically integrating the point-source plume equation (Formula 1),

$$
C(x, y, z)=\frac{Q}{2 \pi \sigma_{y} u} \exp \left(-\frac{y^{2}}{2 \sigma_{y}^{2}}\right)\left[\exp \left(-\frac{(z-H e)^{2}}{2 \sigma_{z}^{2}}\right)+\exp \left(-\frac{(z+H e)^{2}}{2 \sigma_{z}^{2}}\right)\right],
$$

where $\mathrm{C}$ is the concentration $\left(\mathrm{g} / \mathrm{m}^{3}\right), \mathrm{x}$ is the downwind distance from the emission source $(\mathrm{m}), \mathrm{y}$ is the crosswind distance from the emission plume centreline $(\mathrm{m}), \mathrm{z}$ is the distance above the ground level (m), $\mathrm{Q}$ is the pollutant emission rate $(\mathrm{g} / \mathrm{s}), H e$ is effective plume-rise height, $u$ is wind speed $(\mathrm{m} / \mathrm{s}), \sigma_{y}$ is horizontal dispersion width (P-G curve) $(\mathrm{m}), \sigma_{z}$ is vertical dispersion width (P-G curve)(m).

With regard to the seasonal variation characteristics of PM10 there were significant differences for the air quality registered in different months in Brăila. The 2009-2018 air quality was the worst in December, $36.5 \mu \mathrm{g} / \mathrm{m}^{3}$ and the best in July, $19.5 \mu \mathrm{g} / \mathrm{m}^{3}$.

Having a seasonal perspective, we can state the fact that the air quality was the best in summer (June-August). There was a pollution proportion of $20.67 \%$ in summer, followed by spring (March May) with $24.63 \%$ and autumn (September - November), $26.42 \%$ on average, respectively. The air quality was the worst $34.5 \%$, in winter (December - February) (Table 1). Lower atmospheric pressure, $1008 \mathrm{hPa}$, resulted in a lower atmospheric pollution in summer, $20.92 \mu \mathrm{g} / \mathrm{m}^{3}$. When the atmospheric pressure was lower, the probability of occurrence of the atmospheric pollution was reduced, especially in summer.

\begin{tabular}{|c|c|c|c|c|c|c|c|}
\hline & $\begin{array}{l}\text { PM10 } \\
\mu \mathrm{g} / \mathrm{m}^{3}\end{array}$ & $\begin{array}{c}\text { Air } \\
\text { temperature } \\
{ }^{\circ} \mathrm{C}\end{array}$ & $\begin{array}{c}\text { Precipitation } \\
1 / \mathrm{m}^{2}\end{array}$ & $\begin{array}{c}\text { Relative } \\
\text { humidity } \\
\%\end{array}$ & $\begin{array}{c}\text { Atmospheric } \\
\text { pressure } \\
\text { hPa }\end{array}$ & $\begin{array}{l}\text { Wind } \\
\text { direction } \\
{ }^{\circ} \text { nord }\end{array}$ & $\begin{array}{l}\text { Wind } \\
\text { speed } \\
\mathrm{m} / \mathrm{s}\end{array}$ \\
\hline Winter & 34,50 & $-1,09$ & 47,53 & 87,83 & 1012,58 & 11,60 & 8,92 \\
\hline Spring & 26,38 & 12,50 & 29,31 & 70,17 & 1009,50 & 10,25 & 4,32 \\
\hline Summer & 20,92 & 23,84 & 26,50 & 66,33 & 1008,08 & 9,33 & 1,38 \\
\hline Autumn & 25,58 & 13,63 & 32,18 & 76,75 & 1012,83 & 11,00 & 2,75 \\
\hline
\end{tabular}

Tab. 1. Seasonal average of PM10 and meteorological parameters, for 2009 - 2018

The probability of occurrence of the atmospheric pollution increases when atmospheric pressure increases in spring. The influences of the atmospheric pressure had a similar effect in autumn $(1012,83$ $\mathrm{hPa}$ ) and a concentration of $25,58 \mu \mathrm{g} / \mathrm{m}^{3}$ and $34,50 \mu \mathrm{g} / \mathrm{m}^{3}$ in winter with $1012,58 \mathrm{hPa}$. Lower relative humidity had the effect of a lower atmospheric pollution in summer whereas higher relative humidity easily led to atmospheric pollution in other seasons, especially in winter. In summer, relative humidity had a value of $66.33 \%$ and a PM10 concentration of $20,92 \mu \mathrm{g} / \mathrm{m}^{3}$. When relative humidity reached $87.83 \%$ the probability of atmospheric pollution increased to the maximum in winter, with a 34.50 $\mu \mathrm{g} / \mathrm{m}^{3}$ PM10 concentration.

The probability of occurrence of the atmospheric pollution had a medium level in autumn and in spring, when relative humidity reached a value close to $70 \%$. In this case the probability of atmospheric pollution was still smaller in comparison with the winter period. The probability speeds up in accordance with the increase of relative humidity.

The impact of wind speed on air quality was mainly different in the four seasons. Under the circumstances of a wind speed around $1.38 \mathrm{~m} / \mathrm{s}$, the probability of atmospheric pollution was reduced in summer. The probability of occurrence of atmospheric pollution was higher when the wind speed was $8.92 \mathrm{~m} / \mathrm{s}$ in winter. Furthermore, a medium level of the wind speed reached a mean probability of 
atmospheric pollution in spring and summer. For example, in spring the wind speed was $4.32 \mathrm{~m} / \mathrm{s}$ with a $26.38 \mu \mathrm{g} / \mathrm{m}^{3}$ PM 10 concentration while in autumn the wind speed was $2.75 \mathrm{~m} / \mathrm{s}$ with a PM 10 concentration of $25.58 \mu \mathrm{g} / \mathrm{m}^{3}$.

Analysing the wind direction, we found that an average of $9.33^{\circ}$ north in summer led to a lower air pollution while $11.60^{\circ}$ north, the highest value corresponds to the higher pollution in winter.

The influences of air temperature had significantly different effects in the four seasons. The atmospheric pollution mainly occurred when air temperature had an average of $1.09^{\circ} \mathrm{C}$ in winter. This phenomenon occurs especially when it develops a thermal inversion layer in winter that would cause a stable atmospheric condition. Consequently, the dispersion of pollutants is reduced and remains accumulated on the soil surface, in the low atmosphere. Likewise, the atmospheric pollution occurred when the air tem perature was around $20^{\circ} \mathrm{C}$. Higher radiation heats urban area in summer.

Atmospheric turbulence and atmospheric instability have a major effect, rapid pollutant dispersion and diffusion. This phenomenon leads to the conclusion that the probability of atmospheric pollution decreased with the increase of air temperature in summer. The average value of air temperature in summer was $23.84^{\circ} \mathrm{C}$ and the PM10 concentration had a value of $20.92 \mu \mathrm{g} / \mathrm{m}^{3}$.

The impact of air temperature on atmospheric pollution was insignificant in spring and autumn. Moreover, precipitation was an im portant influence factor upon the atmospheric pollution. The impact of precipitation on the possibility of atmospheric pollution was obviously different in the four seasons. A larger amount of precipitation resulted in major pollution, whereas a small quantity of precipitation resulted in lower air pollution. In winter the 2009- 2018 average of precipitation was $47.53 \mathrm{l} / \mathrm{m}^{2}$ and the PM10 concentration was of $34.50 \mu \mathrm{g} / \mathrm{m}^{3}$, in comparison with summer when the PM10 concentration was $20.92 \mu \mathrm{g} / \mathrm{m}^{3}$ and the precipitation average level was $26.501 / \mathrm{m}^{2}$. In spring the average of precipitation was $29.31 \mathrm{l} / \mathrm{m}^{2}$ while in autumn was $32.18 \mathrm{l} / \mathrm{m}^{2}$.

The diffusion, dilution and accumulation of the pollutants are influenced by meteorological conditions. Pollutant concentration depends to a great extent on meteorological conditions even under the same conditions of pollutant sources. In this paper, the correlation degrees between PM10 and meteorological factors, including relative humidity, precipitation, atmospheric pressure, air temperature, wind speed and wind direction were analysed by using the SPSS software (Figure 1).
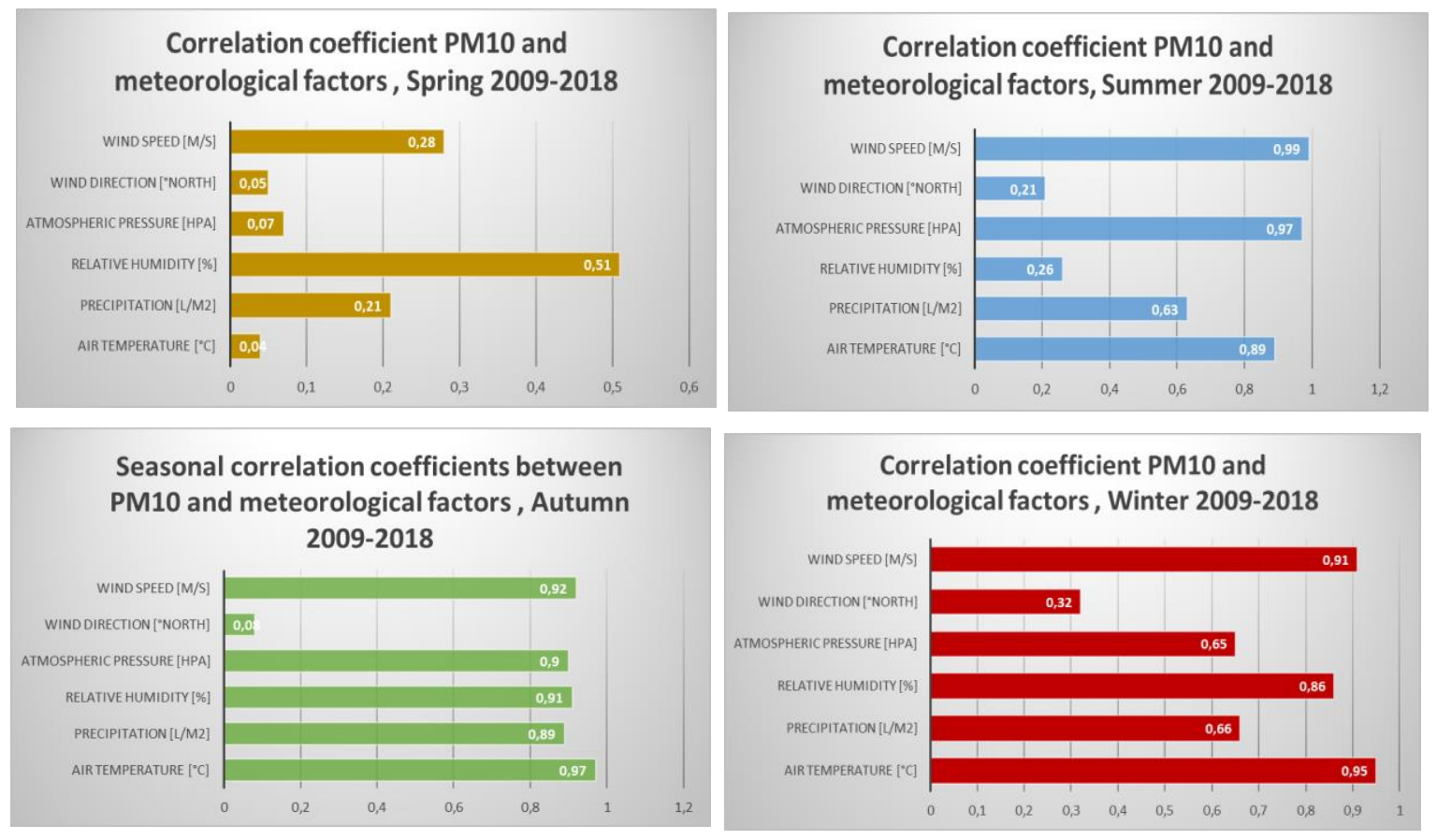

Fig. 1. Correlation of coefficients between PM10 and meteorological factors, 2009 - 2018 
The relationships between PM10 and meteorological factors were complex. The correlation degrees were particularly influenced by seasons. The dominant meteorological factors influencing the atmospheric pollution were different in each season. The influence of air temperature on PM10 was most significant in winter with the worst air quality. Air temperature, wind speed and atmospheric pressure were the dominant meteorological factors in spring. In addition, the impact of precipitation should not be omitted.

Furthermore, air temperature, precipitation, relative humidity, wind speed and atmospheric pressure had an evident impact on PM10 in autumn. In summer when the air quality was the best, air temperature, wind speed and atmospheric pressure influenced PM10. On the whole, air temperature, wind speed and atmospheric pressure were the most important meteorological parameters influencing PM10, followed by relative humidity and precipitation. Wind direction has the lowest influence on the PM10 dispersion in an urban area.

The METI-LIS model was used to produce PM10 seasonal dispersion maps for 2009-2018, which are presented in figure 2.
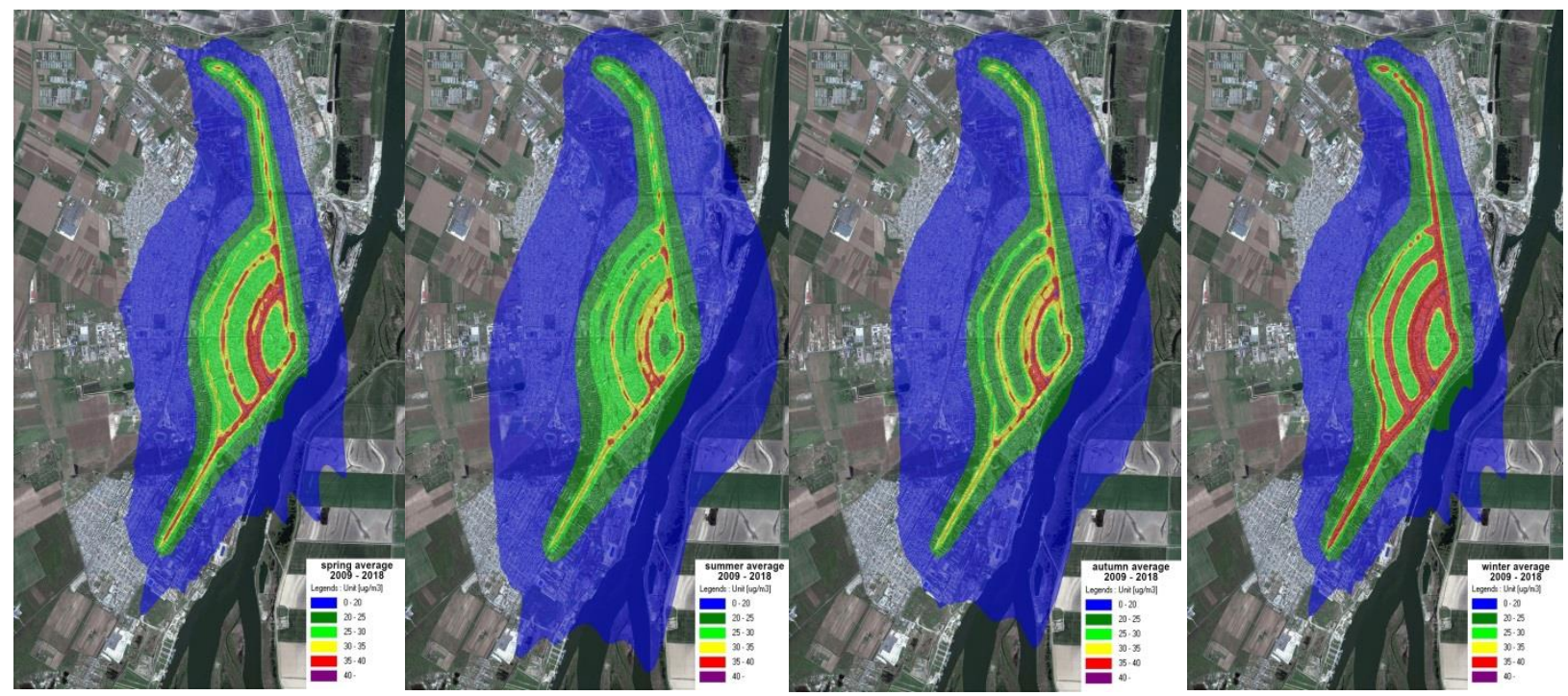

Fig. 2. Dispersion of PM10 for 2009-2018. PM10 concentrations between 0 and $20 \mu \mathrm{g} / \mathrm{m}^{3}$ are displayed in blue colour, the concentrations from 20 to $25 \mu \mathrm{g} / \mathrm{m}^{3}$ are displayed in dark green, 25-30 $\mu \mathrm{g} / \mathrm{m}^{3}$ - in light green, 30-35 $\mu \mathrm{g} / \mathrm{m}^{3}$ - in yellow, 35-40 $\mu \mathrm{g} / \mathrm{m}^{3}$ - in red and concentrations over $40 \mu \mathrm{g} / \mathrm{m}^{3}$ - in violet. Note that the intense green/blue on the SE of the map is due to superposition with the dark colours used in the map

For the purpose of obtaining a spatial distribution of seasonal averages of PM10 emission in Brăila four maps were created. A different scale pattern provides distinct influence on the air quality dispersion and assesses sundry precision of air quality analyses. The METI-LIS soft calculates the PM10 concentration dispersion in a wide area, such as Brăila with a $50 \times 50 \mathrm{~m}$ square spatial grid. In order to determine a high precision of PM10 dispersion we should use smaller grids. The most polluted areas were in the closeness of crowded streets and boulevards in connection with the traffic.

The highest PM10 concentration has been registered alongside the major streets in winter in the interval 2009-2018, with some intermittence on the outskirts of Brăila. In spring and autumn, the PM10 concentration was lower compared to winter, but higher than in summer. The lowest level of PM10 pollution is observed in the summer season.

Several intermittencies are outlined progressively in the city centre and disappear towards the less circulated areas. This phenomenon may occur due to the influence of meteorological parameters, i.e. the wind speed, air temperature and relative humidity. Likewise, a detailed analysis of the four maps points out that spots of PM10 crop up close to the cross-roads and near the traffic lights. 


\section{CONCLUSIONS}

In reality, the effects of meteorological conditions on PM10 atmospheric pollution were evidently different in the four seasons, during the analysed period. There were clearly seasonal variations of atmospheric pollution in Brăila. The air quality was the best in summer, followed by autumn and spring, and the air quality was the worst in winter. The influence of meteorological parameters (including air temperature, relative humidity, atmospheric pressure, wind speed, wind direction and precipitation) on atmospheric pollution was analysed by using the correlation analysis method.

On the whole, air temperature and wind speed were the most important meteorological parameters influencing PM10, followed by atmospheric pressure, relative humidity and wind direction and precipitation.

Nevertheless, the prevailing meteorological factors influencing the PM 10 atmospheric pollution were different in each season. The influence of wind speed on PM10 was most significant in spring. Wind speed and air temperature were the main meteorological factors in summer. In autumn the most important parameter was air temperature, while relative humidity had a significant contribution in winter. In addition, wind direction had an important influence on atmospheric pollution. Besides this, for the period 2009 -2018, air tem perature and wind speed had the most considerable impact on PM10 dispersion.

Taking all of the afore-mentioned aspects into account, this paper has analysed the seasonal specific feature of PM10 and its dependence on meteorological factors between 2009 and 2018, and the final purpose is the feasible actions to ameliorate the air quality in Brăila urban area. All in all, it is extremely important to explore and to understand the impact of different meteorological factors on the atmospheric pollution and the effects on human health, taking into consideration the urbanization process.

\section{REFERENCES}

[1] Zeger S.L., Thomas D., Dominici F., Samet J.M., Schwartz J., Dockery D., Cohen A. Exposure measurement error in time-series studies of air pollution: concepts and consequences. Environ Health Perspect, 108 (5) (2000), 419-426. doi: 10.1289/ehp.00108419

[2] Harrison R.M., Jones A.M., Lawrence R.G. Major component composition of $\mathrm{PM}_{10}$ and $\mathrm{PM}_{2.5}$ from roadside and urban background sites. Atmos. Environ, 38 (27) (2004), 4531-4538. doi: 10.1016/j.atmosenv.2004.05.022

[3] Pozzi R., Berardis B.D., Paoletti L., Guastadisegni C. Winter urban air particles from Rome (Italy): effects on the monocytic-macrophagic RAW 264.7 Environ. Res., 99 (3) (2005), 344-354. doi: 10.1016/j.envres.2005.02.004

[4] Liu Y., Park R.J., Jacob D.J., Li Q., Kilaru V., Sarnat J.A. Mapping annual mean ground-level PM2.5 concentrations using Multi angle Imaging Spectro radiometer aerosol optical thickness over the contiguous United States. J. Geophys. Res., 109 (D22206), 2004, 1-10. doi: 10.1029/2004JD005025

[5] Muir D., Laxen D.P.H. Black smoke as a surrogate for PM10 in health studies. Atmos. Environ., 29 (8) (1995), 959-962. Available at: http://pascal-francis.inist.fr/vibad/index.php?action=getRecordDetail\&idt= 6340196

[6] Cogliani E. Air pollution forecast in cities by an air pollution index highly correlated with meteorological variables. Atmos. Environ., 35 (16) (2001), 2871 -2877. doi: 10.1016/S1352-2310(01)00071-1

[7] Lee S., Ho C.-H., Choi Y.-S. High-PM10 concentration episodes in Seoul, Korea: background sources and related meteorological conditions. Atmos. Environ., 45 (39) (2011), 7240-7247. doi: 10.1016/j.atmosenv.2011.08.071 
[8] Mamtimin B., Meixner F.X. Air pollution and meteorological processes in the growing dryland city of Urumqi (Xinjiang, China). Sci. Total Environ, 409 (7) (2011), 1277-1290. doi: 10.1016/j.scitotenv.2010.12.010

[9] Unal Y.S., Toros H., Deniz A., Incecik S. Influence of meteorological factors and emission sources on spatial and temporal variations of PM10 concentrations in Istanbul metropolitan area. Atmos. Environ., 45 (31) (2011), 5504-5513. doi: 10.1016/j.atmosenv.2011.06.039

[10] Akyüz M., Çabuk H. Meteorological variations of PM2.5/PM10 concentrations and particle-associated polycyclic aromatic hydrocarbons in the atmospheric environment of Zonguldak, Turkey. J. Hazard. Mater., 170 (1) (2009), 13-21. doi: 10.1016/j.jhazmat.2009.05.029

[11] Oanh K., Chutimon P., Ekbordin W., Supat W. Meteorological pattern classification and application for forecasting air pollution episode potential in a mountain-valley area. Atmos. Environ., 39 (7) (2005), 1211-1225. doi: 10.1016/j.atmosenv.2004.10.015

[12] Fuller G.W., Green D. Evidence for increasing concentrations of primary PM10 in London. Atmos. Environ., 40 (32) (2006), 6134-6145. doi: 10.1016/j.atmosenv.2006.05.031

[13] Murariu G., Hahiue V., Georgescu L., Arseni M., Iticescu C., Murariu A., Buhociu F., Nistor N. Study on the influence of atmospheric parameters on the accuracy of the geodetic measurements. AIP Conference Proceedings, 1796 (1) (2017) 040009, 1-4. doi: 10.1063/1.4972387

[14] Hooyberghs J., Mensink C., Dumont G., Fierens F., Brasseur O. A neural network forecast for daily average PM10 concentrations in Belgium. Atmos. Environ., 39 (18) (2005), 3279-3289. doi: 10.1016/j.atmosenv.2005.01.050

[15] Tian G., Qiao Z., Xu X. Characteristics of particulate matter (PM10) and its relationship with meteorological factors during 2001-2012 in Beijing. Environ Pollut., 192 (2014), 266-274. doi: 10.1016/j.envpol.2014.04.036

[16] Zhang Q.H., Zhang J.P., Xue H.W. The challenge of improving visibility in Beijing. Atmos. Chem. Phys., 10 (2010), 7821 - 7827. doi: 10.5194/acp-10-7821-2010

[17] Hu M., Jia L., Wang J., Pan Y. Spatial and temporal characteristics of particulate matter in Beijing, China using the empirical mode decomposition method. Sci. Total Environ., 458-460 (2013), 70-80. doi: 10.1016/j.scitotenv.2013.04.005

[18] Turner D.B., Workbook of Atmospheric Dispersion Estimates: An Introduction to Dispersion Modelling (2nd Edition). CRC Press, 2004.

[19] Kouchi H., Shimomura K., Hata S., Hirota A., Wu G.J. et al. Large-scale analysis of gene expression profiles during early stages of root nodule formation in a model legume. DNA Res., 11 (4) (2004), 263 274. doi: $10.1093 /$ dnares/11.4.263

Address: Mariana Carmelia Bălănică Dragomir, Cristian Munteniță, Daniela Ecaterina Zeca, Dunărea de Jos University of Galați, Strada Domnească 47, Galați, Romania;

Aurel Gabriel Simionescu, Constantin Brâncoveanu University of Pitesti, Strada Rubinelor 16, Brăila, Romania;

Iryna Kramar, Nataliia Marynenko, Ternopil Ivan Puluj National Technical University, 56, Ruska Str., Ternopil, 46001, Ukraine.

E-mail: carmelia.dragomir@ugal.ro,daniela.zeca@ugal.ro,ira_kramar@yahoo.com,n_marynenko@ukr.net Received: 04.09.2019; revised: 20.11.2019.

Баланіца Драгомір Маріана Кармелія, Мунтеніта Крістіан, Сіміонеску Аурель Габріель, Даніела Єкатеріна Зека, Крамар Ірина, Мариненко Наталія. Сезонна і просторова варіація РМ10 в міській місцевості Румунії. Журнал Прикарпатського університету імені Василя Стефаника, 6 (3-4) (2019), 7-14. 
У статті проаналізовано циклічну дисперсію масової концентрації РМ10 у міській місцевості в Південній Румунії. Південна Румунія вважається територією, яка має середній рівень забруднення протягом останніх десяти років (2009-2018 роки). Просторову дисперсію концентрації РМ10 отримували, використовуючи м'який знос METI-LIS для кожного сезону. Мета дисперсійних моделей - оцінити розподіл концентрації забруднюючих речовин з урахуванням дифузії. Були використані середні вимірювання PM10 та метеорологічні параметри в якості вхідних даних. У статті спостерігається очевидна сезонна зміна концентрації РМ10. Для встановлення заходів держави (в т.ч. економічного характеру) щодо вдосконалення контролю над забрудненням атмосфери будо проаналізовано механізм їі забруднення. Визначено, що якість повітря в цілому покращувалася навесні та вдітку порівняно з двома іншими періодами. Щодо сезонних кодивань характеристик PM10, то встановлено значні відмінності у якості повітря, зафіксованому у різні місяці у досліджуваному регіоні. Вплив температури повітря на забруднення атмосфери спостерігали весною та восени; крім того, виявлено, що атмосферні опади є важдивим фактором впливу на забруднення атмосфери. Встановлено, що вплив опадів на можливість забруднення атмосфери був різним у кожному з чотирьох сезонів. Результати досліджень вказують на те, що метеорологічні параметри, що впливають на забруднення повітря, стають активними в холодні сезонні дні. Показано, що відносна вологість і швидкість вітру - це метеорологічні параметри, що впливають на РМ 10. 3'ясовано, що ймовірність забруднення атмосфери зменшувалася зі збільшенням температури повітря влітку. Результати досліджень свідчать також про те, що картографування забруднення повітря можна покращити за допомогою моделей дисперсії атмосфери та вимірювань на місці.

Кдючові слова: РМ10; забруднення повітря; метеорологічні параметри; сезонні зміни, дисперсійна модель. 